\title{
Стратегии борьбы с микотоксикозами птицы
}

Брылина B.E., кандидат биологических наук, доцент кафедры иммунологии и биотехнологии Московская государственная академия ветеринарной медицины и биотехнологии - МВА им. К.И.Скрябина Брылина М.А., кандидат ветеринарных наук ООО «ПРОВЕТ»

Аннотащия: Для эффректибной борьбы с микотоксикозами необходимо сочетание нескольких стратегий адсорбции микотоксинов адсорбентами, ферментативной нейтрализации микотоксинов и использования иммуномодуляторов для преодоления иммуносупрессивного действия микотоксинов. Элиминатор микотоксинов ЭЛИТОКС ${ }^{\circledR}$ обладает подобным действием, обеспечивает защиту печени, кищечника и клеток иммунной системы от боздействия микотоксинов. Терапевтическое действие ЭЛитОкС® доказано экспериментально $\mathcal{b}$ результате маситабных исследований на примере фуумонизина - одного из представителей фузариотоксинов. Результаты исследований представлены в данной статье.

Ключебые слова: микотоксины, фумонизин, адсорбент, фрерментная нейтрализация микотоксинов, иммуномодулятор, ЭЛИТОКС ${ }^{\circledR}$.

В январе 2020 г. в Бангкоке состоялся международный форум, посвященный вопросам этиопатогенеза, профилактики, диагностики и лечения микотоксикозов сельскохозяйственных животных. Для эффективной борьбы с микотоксикозами форум обозначил необходимость сочетания трех стратегий. Ученые всего мира единодушно сформулировали основные направления этих стратегий.

На первый план выдвигается базовая стратегия по элиминации микотоксинов путем адсорбции, связывания их в желудочнокишечном тракте (ЖКТ) животных специальными веществами-адсорбентами.

Вторая, основная по эффективности, стратегия заключается в нейтрализации активности микотоксинов с помощью ферментов.

Третья, дополнительная, но не менее важная стратегия - это борьба с иммуносупрессией, развивающейся в результате действия микотоксинов. Все стратегии имеют свои

особенности.

Стратегия 1-я - устранение микотоксинов путем адсорбции

Данная стратегия направлена на снижение биодоступности токсинов, при этом резко снижается их концентрация, падает количество токсинов, всасывающихся из кишечника в кровь и далее попадающих в органы-мишени .

Наиболее часто адсорбенты микотоксинов используются для предотвращения поступления их в организм животных с кормом. Однако следует подчеркнуть, что эффективность действия адсорбента определяется стабильностью комплекса «адсорбент-микотоксин» в ЖКТ животного. Только при высокой стабильности связанные микотоксины успешно выводятся из организма с мочой и фекальными массами. Важным фрактором, влияющим на стабильность комплекса, служит постоянно меняющиеся уровни $\mathrm{pH}$ среды на всем протяжении ЖКТ. При смене рН комплекс может разрушиться, что приведет к десорбции микотоксина. Поэтому оценка эффрективности адсорбентов должна включать характеристику стабильности комплекса не «в пробирке», а на протяжении всего ЖКT in vivo.

Учитываю эти условия, бельгийская компания Impextraco разработала продукт со всеми необходимыми свойствами адсорбента ЭЛИТОКС ${ }^{\circledR}$, элиминатор микотоксинов. Он содержит комбинацию нескольких типов алюмосиликатов, подобранных на основании их физико-химических свойств: заряда, размера пор, доступности поверхности этих минералов для связывания токсинов. Все эти свойства необходимы для эффективного преимущественного удаления микотоксинов и предотвращения связывания питательных веществ, лекарственных средств и кормовых добавок. Многочисленные научные исследования доказывают отсутствие адсорбции перечисленных веществ при использовании 


\section{ЭЛИТОКС с кормом.}

Стратегия 2-я - инактивация микотоксинов с помощью ферментов

В природе существует широкий спектр ферментов микробного, растительного и животного происхождения, нейтрализующих активность микотоксинов. В состав ЭЛИТОКС входят очищенные растительные экстракты с ферментативной нейтрализующей микотоксины активностью. Неоспоримым преимуществом использования ферментов растительного происхождения служит их немедленная биодоступность, что отсутствует у ферментов, источником которых служат микроорганизмы. Отпадает необходимость создания в кишечнике оптимальных условий для роста и размножения микроорганизмов-продуцентов ферментов, отсутствует проблема конкуренции последних с естественной микрофлорой кишечника за питательные вещества.

элитокС® доказал свою эффективность in vivo

В настоящее время исследователи постоянно обнаруживают новые микотоксины или новые метаболиты уже известных микотоксинов, однако все они остаются малоизученными. Именно поэтому компания Impextraco постоянно инвестирует значительные суммы в исследования по изучению патогенных свойств микотоксинов и разработку средств борьбы с микотоксикозами животных. По мнению компании, наиболее достоверных результатов подобных исследований можно достичь лишь в экспериментах in vivo, учитывая особенности патогенеза микотоксикозов у различных видов животных. В связи с этим испытание эффективности ЭЛИТОКС проводятся как в испытательных центрах компании в контролируемых экспериментальных условиях, так и в полевых условиях.

Компания Impextraco тщательно планирует испытания ЭлИТОКС in vivo, применяет передовое оборудование, использует высокочувствительные биомаркеры для выявления самых ранних признаков микотоксикозов. Биомаркерами называют определенные биологические показатели в организме животных, они изменяются в первую очередь, когда продуктивность животных еще остается неизменной. Так, в качестве биомаркеров используются количественные показатели иммунного статуса, а именно процентный состав и общее количество лейкоцитов периферической крови. С этой целью применяется метод проточной цитометрии. Таким образом, эффективность ЭЛИТОКС дополнительно подтверждается путем количественной оценки основных иммунокомпетентных клеток - макрофагов и лимфоцитов, чутко реагирующих на иммуносупрессивное действие даже низких доз микотоксинов.

Стратегия 3-я - борьба с иммуносупрессией

Ферменты печени, осуществляющие детоксикацию организма животных в условиях постоянного потребления корма, контаминированного микотоксинами, лишь частично могут их нейтрализовать. Данное обстоятельство ведет к прогрессированию микотоксикозов. Поэтому крайне важно защитить печень животных и поддержать их иммунитет.

С этой целью в состав ЭЛИТОКС включены натуральные ингредиенты, обладающие иммуностимулирующим действием и оказывающие антибактериальное и проти- вогрибковое действие, предотвращая, тем самым, развитие вторичных инфекций.

ЭЛИТОКС снижает воспалительную реакцию, уменьшает окислительный стресс клеток слизистой оболочки кишечника, предотвращая синдром «дырявого» кишеч ника и бактериальную транслокацию.

Микотоксины обладают выраженным иммуносупрессивным действием. Особенно чувствительны к микотоксинам макрофаги, Ви Т-лимфоциты, натуральные киллеры. Кроме того, доказано, что микотоксины способны изменять синтез и секрецию цитокинов, регулирующих иммунные реакции, и подавлять, таким образом, иммунный ответ, в том числе синтез антител.

Многочисленные исследования эффективности различных адсорбентов и ЭЛИТОКС на свиньях, жвачных и птице показали, вопервых, что количественная оценка лейкоцитов методом проточной цитометрии как биомаркеров изменений иммунного статуса животных под действием микотоксинов является приемлемой сенсорной системой. Во-вторых, ЭЛИТОКС значительно снижал биодоступность широкого спектра микотоксинов в кишечнике и предотвращал изменения биохимических показателей крови и количество циркулирующих иммунных клеток.

Результаты исследования эффективности ЭЛИтОКС против фумонизина

Целью исследования являлась оценка влияния микотоксина фумонизина на иммунный статус бройлеров; анализ изменения биомаркеров крови под действием фумонизина, а также оценка эффективности элиминатора мико- 


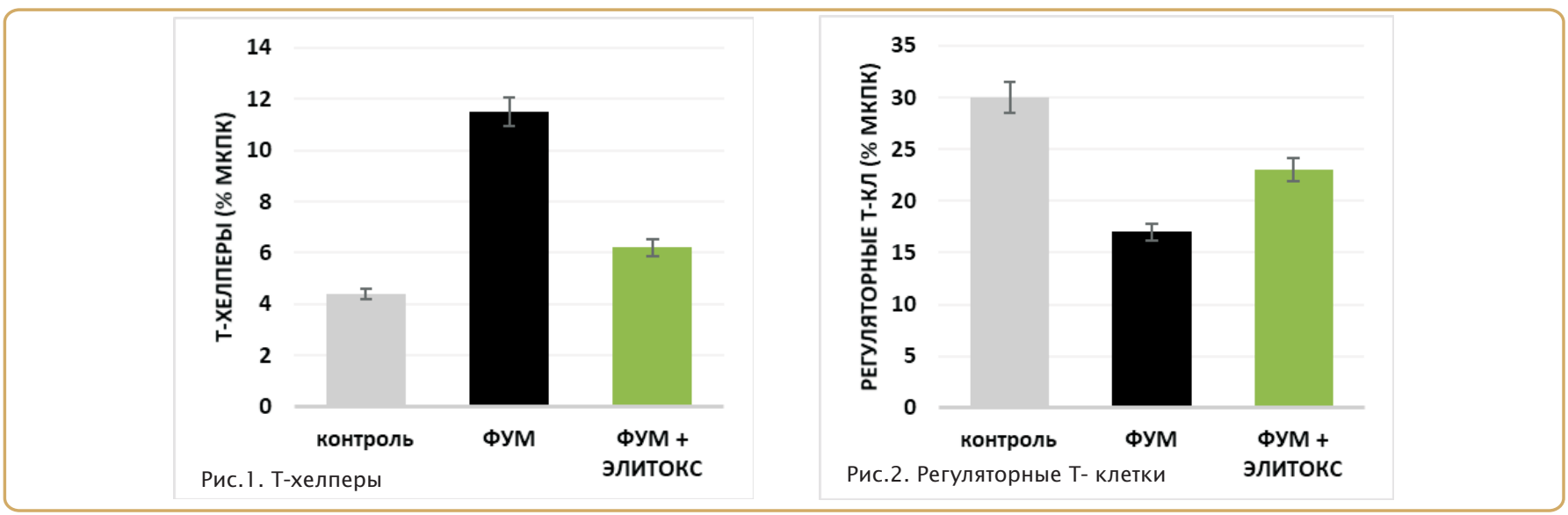

токсинов ЭЛИТОКС против данного микотоксина.

Исследование провели на базе Университета штата Парана (UFPR), Бразилия. В опыте участвовали суточные цыплята кросса Кобб500, которых случайным образом распределили на 3 группы: контрольная группа - с неконтаминированным кормом и без добавления ЭЛИТОКС, группа с контаминированным фумонизином кормом, группа с контаминированным фумонизином кормом и ЭЛИТОКС В стандартной рекомендуемой дозировке. Токсическое воздействие фумонизина на иммунные клетки оценивали путем подсчета лейкоцитов периферической крови для каждой группы методом проточной цитометрии.

Микотоксины, поступая с кормом в кишечник, нарушают его барьерную функцию и провоцируют бактериальную транслокацию из просвета кишечника через слизистую оболочку в более глубокий слой - подслизистую оболочку кишечника (lamina propria), место формирования локального иммунного ответа. При этом чрезвычайно важно поддерживать толерантность иммунной системы животных к питательным элементам корма и дифференцировать иммунную реакцию против токсинов и нутриентов. Для этого существуют регуляторные Т-лимфоциты (Treg), целью которых является предотвращение чрезмерной иммунной реакции, ведущей к воспалению или повышенной проницаемости слизистой кишечника, подавление пролиферации эффекторных иммунных клеток Т-хелперов (Тh) и Т-киллеров.
Как показало исследование, присутствие фумонизина в корме бройлеров значительно снизило количество Treg и увеличило содержание Th в подслизистой оболочке кишечника птицы. Это означает «переключение» локальной иммунной реакции в кишечнике из состояния толерантности в реакцию воспаления. При этом в группе с ЭЛИТОКС зафиксировали увеличение количества Tregклеток и снижение количества Th, следовательно, ЭЛИТОКС предотвратил развитие воспалительной реакции в кишечнике при наличии фумонизина в корме (диагр. 1 и 2).

Цитотоксические Т-лимфоциты - это иммунные клетки, уничтожающие клетки организма, инфицированные внутриклеточными микроорганизмами, а также злокачественные клетки. Они экспрессиру-

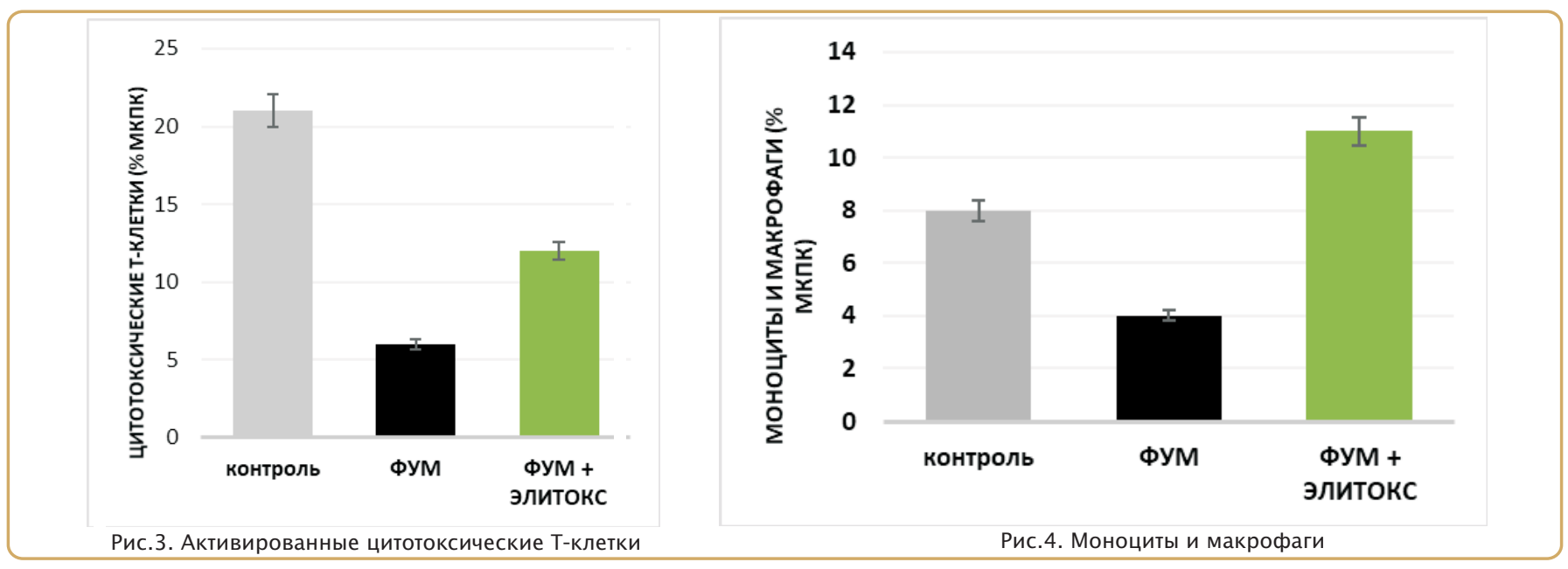


ют Т-клеточные рецепторы, которые могут распознавать вирусные и онко-антигены. При снижении их количества, что наблюдали в группе бройлеров, потреблявших контаминированный фумонизином корм, снижается и резистентность организма животных по отношению к вирусным, протозойным патогенам и злокачественным новообразованиям. В группе с ЭЛИТОКС количество цитотоксических Т-лимфоцитов осталось на уровне физиологической нормы даже при скармливании контаминированного фумонизином корма (диагр. 3).

Моноциты и макрофраги - это клетки врожденного иммунитета, первой линии защиты организма. Моноциты являются клеткамипредшественниками дендритных клеток и макрофагов. Макрофаги активно захватывают, поглощают и переваривают бактерии, остатки погибших клеток и другие чужеродные или токсичные для организма частицы путем фагоцитоза. Они играют решающую роль в неспецифической защите, помогают инициировать специфические защитные механизмы путем привлечения других иммунных клеток, а также играют решающую роль в восстановлении тканей. При этом затраты энергии этими клетками считаются низкими. Снижение количества этих иммунных клеток делает животное более восприимчивым к вторичным инфекциям. Известно, что микотоксины вызывают снижение количества моноцитов и макрофагов в организме и развитие различных вторичных инфекций, которые, в свою очередь, приводят к еще большим потерям продуктивности, чем прямое воздействие отдельных микотоксинов.

Исследование показало, что процент моноцитов и макрофагов от мононуклеарных клеток периферической крови значительно снизился в группе, потреблявшей контаминированный фумонизином корм, по сравнению с контрольной группой. При этом в группе с ЭЛИТОКС и контаминированным кормом мы видим реакцию иммуномодуляции и тенденцию увеличения моноцитов и макрофагов даже по сравнению с контрольной группой (диагр. 4). Это не только подтверждает иммуностимулирующую функцию ЭЛИТОКС, но и предполагает лучшую защиту организма птицы от инфекционных болезней.

\section{Выводы}

Продемонстрировано иммуносупрессивное действие микотоксинов (в данном случае фумонизина) на иммунитет птицы и иммуномодулирующие свойства ЭЛИТОКС. Отмечено провоспалительное действие фумонизина в кишечнике птиц, снижение количества регуляторных Т-лимфоцитов и увеличение популяции Т-хелперов под действием этого микотоксина. Иммунная реакция у птицы, потреблявшей контаминированный корм, была снижена, что подтверждалось статистически достоверным снижением количества моноцитов и макрофагов периферической крови. В то же время, ЭЛИТОКС явно противодействовал данному эффекту фумонизина на иммунитет птицы. Можно сделать вывод, что ЭЛИТОКС эффективен для устранения и предупреждения воздействия фумонизина на иммунную систему птицы.

Библиографический сиисок предостабляется по заиросу.

Для контакта с авторами:

Брылина Вера Евгеньевна

E-mail: integrin07@rambler.ru

Брылина Мария Александровна

E-mail: brylina.provet@ya.ru

\title{
The Strategies of the Counteraction to Avian Mycotoxicoses
}

\author{
Brylina V.E. ${ }^{1}$, Brylina M.A. ${ }^{2}$ \\ ${ }^{1}$ Moscow State Academy of Veterinary Medicine and Biotechnology of K.I. Skryabin; 2"Provet" Co., Ltd.
}

Summary: The effective counteraction to mycotoxicoses involves the combination of different strategies: adsorption of the toxins; enzymatic neutralization of the toxins; and mitigation of immunosuppression induced by the toxins by immunomodulators. The mycotoxin eliminator Elitox ${ }^{\circledR}$ (Impextraco, Belgium) combines all three strategies; it protects liver, intestine and cells of the immune system from the effects of mycotoxins. The large-scale experiments proved the therapeutic effects of Elitox ${ }^{\circledR}$ on the example of fumonisin, a fusariotoxin. The results of these experiments are briefly reviewed.

Key words: mycotoxins, fumonisin, adsorbent, enzymatic neutralization of mycotoxins, immunomodulator, Elitox ${ }^{\circledR}$. 